\title{
Meta Analysis: The Effect of Edmodo Assisted Physics Learning Media on Student Learning Outcomes
}

\author{
Naurah Nazifah ${ }^{*}$, Nurul Azmi $^{1}$, Putri Nurhaliza ${ }^{1}$, Desnita $^{2}$ \\ ${ }^{1}$ Magister of Physics Education, Faculty of Mathematics and Natural Sciences, Universitas Negeri Padang, Indonesia \\ 2 Physics Department, Faculty of Mathematics and Natural Sciences, Universitas Negeri Padang, Indonesia
}

DOI: $10.29303 /$ jppipa.v7iSpecialIssue.822

\section{Article Info}

Received: June 29th, 2021

Revised: December $5^{\text {th }}, 2021$

Accepted: December 11 th, 2021

\begin{abstract}
The industrial revolution 4.0 requires humans to have 21 st century skills. In essence, education is expected to produce students who have the quality to live as individuals who are creative, innovative, intelligent, and globally competent. The purposes of this study are to: 1) Determine the effect of Edmodo media on student learning outcomes in the aspect of high school level class levels. 2) Determine the effect of Edmodo media on student learning outcomes on the material used. 3) Determine the effect of Edmodo media on student learning outcomes. The type of research used is meta-analysis. The articles analyzed in this study amounted to 15 articles published in 2014-2021. The average overall effect size of using Edmodo-assisted learning media on high school students' learning outcomes is 2.51 in the high category. The Edmodo-assisted physics learning media provides an effect size on the XI SMA level with an average of 2.91 in the high category, the Edmodo-assisted physics learning media provides an effect size on the XI SMA level with an average of 2.15 in the high category. The highest average value of the effect size of Edmodo-assisted learning media on global warming material with a value of 7.50 in the high category, while the lowest average value of the effect size of Edmodo-assisted learning media on optical instrument materials with a value of 0.87 .
\end{abstract}

Keywords: Meta-analysis; Learning media; Edmodo.

Citation: Nazifah, N., Azmi, N., Nurhaliza, P., \& Desnita, D. (2021). Meta Analysis: The Effect of Edmodo Assisted Physics Learning Media on Student Learning Outcomes. Jurnal Penelitian Pendidikan IPA, 7(Speciallssue), $231-237$. https://doi.org/10.29303/jppipa.v7iSpeciallssue.822

\section{Introduction}

The industrial revolution 4.0 requires humans to have 21 st century skills. The century where various information is available anywhere and anytime so that it can be obtained by everyone in all corners of the world without exception. 21st century learning is learning that requires students to have the skills or competencies that need to be possessed to face the developments of this globalization era (Desnita, et al., 2021). The development of science and technology (IPTEK) is so rapid, there is no longer a space limit for us to communicate with each other. The development of science and technology has an impact on global challenges and competition faced by every country. In Indonesia, it is necessary to create quality human resources to be able to compete with the wider community. On this basis, 21st century education should be able to develop student competencies in superior knowledge, skills, attitudes and values (Asrizal, et al., 2018).

Education is very important for the life and progress of the nation, because starting from education, strong human resources are created and able to make changes to support the development of the country in a more advanced direction (Ali, 2013). Since in the womb, parents have introduced education to their children, after birth then grow and develop, learning to children

\footnotetext{
*Email: naurahnazifah13@gmail.com
} 
is given through basic education, secondary education to college. In essence, education is expected to produce students who have the quality to live as individuals who are creative, innovative, intelligent, and globally competent (Usmeldi, et al., 2017). Thus, one of the efforts is to improve the quality of education.

Improving the quality of education is one of the national development programs. All educational institutions, from basic education to higher education, strive to improve the quality of education in accordance with their respective fields. Schools must increase the creativity of teachers and pay attention to students to be more actively involved in learning activities (Desnita, et al., 2020).

In education, technology must be used appropriately in order to improve the quality of learning experienced by students (Yuberti, 2015). Technological developments are marked by the emergence of various technology-based activities, such as e-commerce, e-government, e-medicine, elaboratory, and e-education, all of which are electronic based. (Hamzah, 2011). In learning, technological developments can be felt, especially media technology used by students in high school (Ghaliyah, et al., 2015).

Physics is a science that is studied at the high school level in the 2013 Curriculum. Physics is a science that studies natural phenomena. (Hidayani, et al., 2016). Physics explains various phenomena that occur in nature (Diani, 2015). And to create students who can glorify the greatness of God. (Setiawan, et al., 2013). In physics, it is important to observe natural events which can basically be studied using appropriate and interesting teaching materials and learning media for students.

Media is very important in learning because it aims to convey information from the source to the recipient of the message and to stimulate students to participate in learning activities (Ambarwulan and Muliyati, 2016). According to AECT (Association of Education and Communication Technology). Media are all forms used for the process of distributing information. While the notion of media is any tool that can be used as a channel for messages to achieve learning objectives. Learning media are tools used by teachers to assist the process of delivering material. Media is anything that can be used to channel messages from the sender to the recipient so that it can stimulate the thoughts, feelings and interests and attention of students in such a way that the learning process occurs (Sadiman, 2006).

One of the online learning applications that can be used as a learning medium is Edmodo. Edmodo is a learning media which contains material, assignments, quizzes, scoring and can be divided into several classes according to the number of classes taught by an educator (Nugroho, 2014). Edmodo helps in the learning process. Edmodo provides a safe and easy way to build virtual classrooms based on class divisions like in a school. Edmodo's display design is almost the same as Facebook's display design. With Edmodo, teachers can easily send grades, assignments, or quizzes to students.

The results of an initial study were carried out by reading from several journals related to the development of Edmodo learning media, obtained some real conditions in the field. The first real condition is that physics textbooks in schools will be easily damaged and torn and the use of physics textbooks is boring and makes students rarely study them because of an unattractive appearance. There are several weaknesses in physics textbooks, including in appearance, manufacturing process and use. This causes a lack of student motivation in learning physics and causes students to be lazy to study. So that many students cheat on exams because of their lazy attitude and lack of awareness to be honest in themselves.

The second real condition is the results of interviews with several physics subject teachers and students that the physics learning carried out has not been as expected. After being identified, information was obtained that the physics learning media used by teachers in learning did not support it. Teachers only use textbooks from several publishers and rarely use ICT-based media. Meanwhile, in the current era of globalization with the development of science and technology, students are required to be able to compete between people and people, groups with groups, the wider community and even between countries.

The formulation of the problem from this research are: 1) How is the influence of Edmodo media on student learning outcomes in the aspect of the high school level class level. 2) How is the influence of Edmodo media on student learning outcomes on the material used. 3) How is the influence of Edmodo media on student learning outcomes.

The purposes of this study are to: 1) Determine the effect of Edmodo media on student learning outcomes in the aspect of high school level class levels. 2) Determine the effect of Edmodo media on student learning outcomes on the material used. 3) Determine the effect of Edmodo media on student learning outcomes.

\section{Method}

The type of research used is meta-analysis. The article analyzed in this study amounted to 15 articles published in 2014-2021, which can be seen Table 1. 
Table 1. List of Articles Meta Analysis

\begin{tabular}{ll}
\hline Article & Author \\
\hline K1 & Pedungge, et al., (2020) \\
K2 & Chandramidi, et al., (2016) \\
K3 & Fadila, (2018) \\
K5 & Ardiansyah, (2019) \\
K6 & Handayani, (2019) \\
K7 & Aulia, et al., (2019) \\
K8 & Aulia, et al., (2018) \\
K9 & Salim and Odja, (2020) \\
K10 & Yuanita, et al., (2016) \\
K11 & Hikmah et al., (2017) \\
K12 & Denny, et al., (2020) \\
K13 & Warjanto, et al., (2014) \\
K14 & Hadjarati, et al., (2020) \\
K15 & Tania, et al., (2020) \\
\hline
\end{tabular}

The data in this study is secondary data because it is obtained from the results of previous research. Data were collected using documentation techniques. The steps of data tabulation are (1) identification of research variables and enter them in the appropriate variable column, (2) identification of the mean and standard deviation of the experimental group and control group data for each research subject, 3) if the standard deviation is not known then can use the $t$ value formula, (4) analyze the data to obtain the effect size value. Effect size is a measure of the magnitude of the effect of a variable on other variables, then the magnitude of the difference and the relationship of a sample. The effect size can be specified in the following statistical parameters (Becker and Park, 2011):

a. Average in one grup

$$
E S=\frac{\bar{x}_{\text {posttest }}-\bar{x}_{\text {pretest }}}{S D_{\text {pretest }}}
$$

b. If the standard deviation is not known then it can be done by $t$ test

$$
E S=t \sqrt{\frac{1}{n_{\text {experiment }}}+\frac{1}{n_{\text {control }}}}
$$

c. Mean and standard deviation of two group pre-post test

$$
E S=\frac{\left(\bar{x}_{p o s t}-\bar{x}_{p r e}\right)_{E}-\left(\bar{x}_{p o s t}-\bar{x}_{p r e}\right)_{C}}{\frac{S D_{\text {preC }}+S D_{\text {preE }}+S D_{\text {post } C}}{3}}
$$

Information:

$$
\begin{array}{ll}
\text { ES } & =\text { Effect size } \\
X_{\text {postest }} & =\text { Posttest average } \\
X_{\text {pretest }} & =\text { Pretest average } \\
S D_{\text {pretest }} & =\text { Standard deviation } \\
X_{E} & =\text { Experimental group mean }
\end{array}
$$

$$
\begin{array}{ll}
X_{C} & =\text { Control group mean } \\
\mathrm{t} & =\mathrm{t} \text { value } \\
\mathrm{n} & =\text { Number of samples } \\
\mathrm{X}_{\text {postE }} & =\text { Mean posttest experimental group } \\
\mathrm{X}_{\text {preE }} & =\text { Mean pretest experimental group } \\
\mathrm{X}_{\text {postC }} & =\text { Mean posttest control group } \\
\mathrm{X}_{\text {preC }} & =\text { Mean pretest control group } \\
\mathrm{SD}_{\mathrm{E}} & =\text { Standard deviation experimental group } \\
\mathrm{SD}_{\mathrm{C}} & =\text { Standard deviation control group }
\end{array}
$$

After the effect size is calculated, it is further categorized at the following levels (Cohen's, 1988)

Table 2. Effect Size Criteria (ES)

\begin{tabular}{ll}
\hline Effect Size & Category \\
\hline ES $<0.2$ & Low \\
$0.2<$ ES $<0.8$ & Medium \\
ES $>0.8$ & High \\
\hline
\end{tabular}

\section{Result and Discussion}

The Effect of Edmodo-Assisted Physics Learning Media based on Student Learning Outcomes

The first result in this study is related to the effect of Edmodo-assisted learning media on high school student learning outcomes. There are 15 articles that fit the first objective. The average effect size value is obtained from the calculation of the effect size of each article. The effect size value of the influence of Edmodo-assisted learning media on high school students' learning outcomes can be seen in Table 3 .

Table 3. The effect size value of the influence of Edmodo-assisted learning media on high school students' learning outcomes

\begin{tabular}{ll}
\hline Article & Effect Size \\
\hline K1 & 7.50 \\
K2 & 1.34 \\
K3 & 1.26 \\
K4 & 1.01 \\
K5 & 1.23 \\
K6 & 1.50 \\
K7 & 1.50 \\
K8 & 3.02 \\
K9 & 9.80 \\
K10 & 1.53 \\
K11 & 0.87 \\
K12 & 1.09 \\
K13 & 1.74 \\
K14 & 2.45 \\
K15 & 1.77 \\
Average Effect Size & 2.51 \\
\hline
\end{tabular}

Based on the data in Table 3. there are 15 articles with different average effect sizes. The average overall 
effect size of using Edmodo-assisted learning media on high school students' learning outcomes is 2.51 in the high category. The average effect size describes that the Edmodo-assisted physics learning media has an effect on student learning outcomes. This shows that the use of Edmodo-assisted physics learning media can improve high school student learning outcomes.

Edmodo is a simple electronic learning media tool that is used to present lesson content, usually all of these smartphone operating systems provide useful tools for students and teachers to interact online outside the classroom, anywhere and anytime (Hourdequin, 2014). Teacher and student interaction is a learning process carried out to transform knowledge, attitudes, and skills (Hamalik, 2007). The use of Edmodo-assisted learning media provides behavioral changes in students that can be observed and measured in the form of knowledge, attitudes, and skills (Putri, et al., 2018).

Effect of Edmodo Assisted Learning Media based on High School Class Level

The second result in this study is related to the influence of Edmodo-assisted physics learning media in terms of grade level. Of the 15 articles included in the article review, there are 7 articles for class X SMA and 8 articles for class XI SMA. The average value of the effect size for the X SMA level is in Table 4.

Table 4. The average value of the effect size for the $X$ SMA level

\begin{tabular}{lll}
\hline Class Level & Article & Effect Size \\
\hline & K1 & 7.50 \\
& K2 & 1.34 \\
K5 & 1.23 \\
& K6 & 1.50 \\
& K7 & 1.50 \\
& K10 & 1.53 \\
& K11 & 0.87 \\
& K15 & 1.77 \\
K3 & 1.26 \\
& K4 & 1.01 \\
& K8 & 3.02 \\
& K9 & 9.80 \\
Average Effect Size & K12 & 1.09 \\
& K13 & 1.74 \\
& & 2.45 \\
\end{tabular}

Based on the data in Table 4. it can be described that the use of Edmodo-assisted learning media has an effect on the learning outcomes of X and XI high school students. The average value of the highest effect size at the XI SMA level is 2.91 in the high category. This shows that the use of Edmodo-assisted physics learning media has an effect on the learning outcomes of class $\mathrm{X}$ high school students.

At the age of 11-12 years and over, children experience a formal operational phase, which is a phase where children are able to think about something that will or may happen and something is abstract. In the learning process students apply various models for high reasoning and require children to actively think and draw meaning from empirical and abstract things (Bujuri, 2018). This is in accordance with the concept of abstract physics learning and physics learning is a science that learns about natural phenomena.

The Effect of Edmodo Assisted Learning Media based on High School Physics Materials

The results of these three meta-analyses related to the influence of Edmodo-assisted physics learning media based on high school physics material can be seen in Table 5.

Table 5. The results of Three Meta-Analyses Related to the Influence of Edmodo-assisted Physics Learning Media Based on High School Physics Material

\begin{tabular}{llll}
\hline Subject matter & Article & Effect Size & $\begin{array}{l}\text { Average Effect } \\
\text { Size }\end{array}$ \\
\hline Impulse & K2 & 1.34 & 1.64 \\
momentum & K4 & 1.01 & \\
& K13 & 1.74 & \\
Static Fluid & K14 & 2.45 & \\
& K5 & 1.23 & 1.38 \\
Dynamic Fluid & K10 & 1.53 & \\
K6 & 1.50 & 1.50 \\
Temperature and & K7 3 & 1.50 & \\
Heat & K9 & 1.26 & 4.69 \\
& K8 & 3.80 & \\
Effort and Energy & K12 & 1.09 & 1.09 \\
Global Warming & K1 & 7.50 & 7.50 \\
Optical Device & K11 & 0.87 & 0.87 \\
Sound Waves & K15 & 1.77 & 1.77 \\
\hline
\end{tabular}

Based on the data in Table 5. the average effect size values for physics learning materials are different, but the average effect size is in the high category. The highest average value of the effect size of Edmodoassisted learning media on global warming material is 7.50. This shows that the Edmodo-assisted learning media has an effect on the learning outcomes of high school students on physics material. With the application of Edmodo-assisted learning media, they carry out learning even though they stay at home and the time used is not limited so that students do not feel bored to learn physics (Hanum, 2013). 


\section{Conclusion}

Based on the results of the research and discussion, it can be concluded that the use of Edmodoassisted physics learning media affects the learning outcomes of X and XI high schooll students. High school physics material on Edmodo-assisted learning media has an effect on high school student learning outcomes. Edmodo-assisted physics learning media has an effect on improving high school student learning outcomes.

\section{References}

Ali, M. (2013). Pendidikan untuk pembangunan nasional: Jakarta. Grasindo. [Indonesian]

Bujuri, D. (2018). Analisis Perkembangan Kognitif Anak Usia Dasar dan Implikasinya dalam Kegiatan Belajar Mengajar. LITERASI (Jurnal Ilmu Pendidikan), 9(1), 37-50. http://dx.doi.org/10.21927/literasi.2018.9(1).37$\underline{50}$ [Indonesian]

Ambarwulan, D., \& Muliyati, D. (2016). The Design of Augmented Reality Application as Learning Media Marker-Based for Android Smartphone. Jurnal Penelitian \& Pengembangan Pendidikan $\begin{array}{llll}\text { Fisika, } & 2(1), & 73 & -\end{array}$ https://doi.org/10.21009/1.02111

Ardiansyah, A. (2019). Efek Model Pembelajaran Kooperatif Tipe Group Investigation (GI) Berbantuan Edmodo Terhadap Hasil Belajar Fisika Siswa Sma. Jurnal Ikatan Alumni Fisika Universitas Negeri Medan, 5(3), 42-46. https://doi.org/10.24114/jiaf.v5i3.14694 [Indonesian]

Asrizal, Amran, A., Ananda, A., \& Festiyed. (2018). Development of adaptive contextual teaching model of integrated science to improve digital age literacy on grade VIII students. Journal of Physics: Conference Series, 1116, 32004. https://doi.org/10.1088/17426596/1116/3/032004

Aulia, L. N., Susilo, S., \& Subali, B. (2018). Perbandingan Model Problem Based Learning Berbantuan Edmodo terhadap Kemandirian Belajar dan Pemahaman Konsep Fluida Dinamis. UPEJ Unnes Physics Education Journal, 7(2), 73-84. https://doi.org/10.15294/upej.v7i2.27470 [Indonesian]

Aulia, L., Susilo, S., \& Subali, B. (2019). Upaya peningkatan kemandirian belajar siswa dengan model problem-based learning berbantuan media Edmodo. Jurnal Inovasi Pendidikan IPA, $5(1)$,

69-78. doi:https://doi.org/10.21831/jipi.v5i1.18707

[Indonesian]

Becker, K., \& Park, K. (2011). Effects of integrative approaches among science, technology, engineering, and mathematics (STEM) subjects on students' learning: A preliminary. Journal of STEM Education, 12(5), 23-38.

Chandramidi, M. (2016). Pengembangan Bahan Ajar Materi Momentum dan Impuls Berbasis Edmodo dan Berpikir Kritis (The Development of Teaching Materials Impuls and Momentum Topics Based on Edmodo and Critical Thinking). Jurnal Teknologi Pendidikan Dan Pembelajaran, 3(1), 55-63. [Indonesian]

Cohen, J. (1988). Statistical Power Analysis for the Behavioral Sciences (2nd ed.). Routledge. https://doi.org/10.4324/9780203771587

Denny, Y. R., Utami, I. S., Rohanah, S., \& Muliyati, D. (2020). The Development of Blended Learning Model using Edmodo to Train Student Critical Thinking Skills on Impulse-Momentum Topic. Jurnal Penelitian \& Pengembangan Pendidikan $\begin{array}{llll}\text { Fisika, } & 6(1), & 113 & -\end{array}$ https://doi.org/10.21009/1.06113

Desnita, D., Hardianti, R., \& Pasaribu, W. (2020). Implementation of Online Learning Method and Its Impact on Students. Seminar Nasional Ilmu Pendidikan Dan Multi Disiplin 3 (SNIPMD 3). (Vol. 3). Retrieved from, https://prosiding.esaunggul.ac.id/index.php/s nip/article/view/60

Desnita, D., Putra, A., Hamida, S., Marsa, P. B., \& Novisya, D. (2021). Quality Test of Student Worksheets Based on Contextual Teaching And Learning for Class XI High School Physics. Jurnal Penelitian Pendidikan IPA, 7(1), 92-101. https://doi.org/10.29303/jppipa.v7i1.600

Diani, R. (2015). Pengembangan Perangkat Pembelajaran Fisika Berbasis Pendidikan Karakter Dengan Model Problem Based Instruction. Jurnal Ilmiah Pendidikan Fisika AlBiruni, 4(2), 243-255. https://doi.org/10.24042/jpifalbiruni.v4i2.96 [Indonesian]

Fadila, N. (2018). Meningkatkan Kemampuan Belajar Fisika Melalui Model Pembelajaran Kooperatif Numbered Heads Together Berbantuan Edmodo. Edutech, 17(2), 176-187, https://doi.org/10.17509/e.v17i2.12729 [Indonesian]

Ghaliyah, S., Bakri, F., \& Siswoyo, S. (2015). Pengembangan Modul Elektronik Berbasis Model Learning Cycle 7e Pada Pokok Bahasan Fluida Dinamik Untuk Siswa Sma Kelas XI. Prosiding Seminar Nasional Fisika (E-Journal), 4, 
SNF2015-II.

Retrieved

from

http://journal.unj.ac.id/unj/index.php/prosidi ngsnf/article/view/4998

Hadjarati, Y., Arota, A., Salim, M., \& Odja, A. (2020). Effectiveness of Edmodo To Improve Senior High School Students' Creative Thinking Skills In Momentum And Impulse Topics. Journal of Physics: Conference Series, 1521, 22065. https://doi.org/10.1088/17426596/1521/2/022065

Hamalik, O. (2007). Proses Belajar Mengajar. Jakarta: Bumi Aksara. [Indonesian]

Hamzah, N.L. (2011). Teknologi komunikasi dan informasi pembelajaran. Jakarta: Bumi Aksara. [Indonesian]

Handayani, M.F. (2019). Efek Model Pembelajaran Problem Based Learning Berbantuan Edmodo Terhadap Kemandirian Belajar Siswa Pada Materi Fluida Statis Kelas Xi Semester I SMAN 1 Binjai Tp 2019/2020. Doctoral dissertation, UNIMED. Retrieved from, http://digilib.unimed.ac.id/37131/ [Indonesian]

Hanum, N. (2013). Keefetifan e-learning Sebagai Media Pembelajaran (Studi Evaluasi Model Pembelajaran E-Learning SMK Telkom Sandhy Putra Purwokerto). Jurnal Pendidikan Vokasi, 3(1). doi:https:// doi.org/10.21831/ipv.v3i1.1584 [Indonesian]

Hidayani, F., Rusilowati, A., \& Masturi. (2016). Pengembangan Bahan Ajar Berbasis Literasi Sains Materi Fluida Statis. UNNES Physics Education Journal, 5(3), 26-31. https://doi.org/10.15294/upej.v5i3.13726 [Indonesian]

Hikmah, N. 2017. Efektivitas Media pembelajaran Edmodo Terhadap Minat Belajar dan Hasil Belajar Siswa pada Materi Fisika Kelas XI IPA SMAN 1 Tanete Rilau. Doctoral dissertation, Universitas Islam Negeri Alauddin Makassar. Retrieved from, http://repositori.uinalauddin.ac.id/4504/ [Indonesian]

Hourdequin, P. (2014). Edmodo: A Simple Tool for Blended Learning. The Language Teacher38.

Mamonto, M., Odja, A., \& Abdjul, T. (2021). The Effect of E-Learning Application through the Use of Whatsapp-Assisted Edmodo on the Students' Learning Outcomes in the Concept of Sound Waves. Jurnal Pendidikan Fisika, 9(1), 56 - 62. doi:https://doi.org/10.26618/jpf.v9i1.4361.

Nugroho, A.A. (2014). Pengembangan Media Pembelajaran Matematika Dengan Strategi Projek Based Learning Berbantuan Edmodo pada Mata Kuliah Statistik Dasar. Seminar Universitas PGRI Semarang: Matematics and sciences forum 2014.

Retrieved

from, http://prosiding.upgris.ac.id/index.php/masif2 014/masif2014/paper/view/491 [Indonesian]

Salim, M., \& Odja, A. (2020). Minimizing misconception on the topic of temperature and heat by edmodo learning media. Journal of Physics: Conference Series, 1521, 22066.

https://doi.org/10.1088/17426596/1521/2/022066

Podungge, N., Paramata, D. D., \& Odja, A. H. (2020). Penerapan E-Learning Berbantuan Media Pembelajaran Edmodo Terhadap Hasil Belajar Siswa Pada Konsep Gejala Pemanasan Global. Konstan-Jurnal Fisika Dan Pendidikan Fisika, 5(2), 77-85. https:// doi.org/10.20414/konstan.v5i2.55

Putri, S., Wahyuni, S., \& Suharso, P. (2018). Penggunaan Media Pembelajaran Edmodo Untuk Meningkatkan Aktivitas Dan Hasil Belajar Siswa Kelas X Pemasaran Di SMK Negeri 1 Jember Tahun Ajaran 2016/2017. Jurnal Pendidikan Ekonomi: Jurnal Ilmiah Ilmu Pendidikan, Ilmu Ekonomi Dan Ilmu Sosial, 11(2), 108-114. https://doi.org/10.19184/jpe.v11i2.6455

[Indonesian]

Sadiman. (2006). Media Pendidikan: Pengertian, Pengembangan, Dan Pemanfaatannya. Jakarta: PT Raja Grafindo. [Indonesian]

Setiawan, A., Sutarto, S., \& Indrawati, I. 2013. Metode Praktikum Dalam Pembelajaran Pengantar Fisika SMA: Studi Pada Konsep Besaran Dan Satuan Tahun Ajaran 2012-2013. Repository Universitas Jember. 285-290. Retrieved from, http://repository.unej.ac.id/handle/123456789/ $\underline{458}$ [Indonesian]

Tania, R., Jumadi, J., \& Astuti, D. (2020). The application of physics e-handout assisted by PBL model use Edmodo to improve critical thinking skills and ICT literacy of high school students. Journal of Physics: Conference Series, 1440, 12037. https://doi.org/10.1088/17426596/1440/1/012037

Usmeldi, U., Amini, R., \& Trisna, S. (2017). The Development of Research-Based Learning Model with Science, Environment, Technology, and Society Approaches to Improve Critical Thinking of Students. Jurnal Pendidikan IPA Indonesia, 6(2), 318-325.

doi:https://doi.org/10.15294/ipii.v6i2.10680

Warjanto, S., Nurhayati, N., \& Azhar, A. (2014). Efektifitas Social Learning Network Berbasis Edmodo Terhadap Hasil Belajar Siswa Sma Pada Materi Alat Optik. Prosiding Seminar Nasional Fisika (E-Journal), 3, 148 - 150. Retrieved from http://journal.unj.ac.id/unj/index.php/prosidi ngsnf/article/view/5497 [Indonesian] 
Yuanita, L. (2017). Efektifitas Problem Based Learning Berbantuan Edmodo Untuk Meningkatkan Prestasi Belajar Fisika Studi Pada Suhu Dan Kalor Kelas X Teknik Kendaraan Ringan SMK Tunas Bangsa Wanareja. ReTII. Retrieved from http://journal.itny.ac.id/index.php/ReTII/articl e/view/446 [Indonesian]

Yuberti, Y. (2015). Peran Teknologi Pendidikan Islam Pada Era Global. Akademika: Jurnal Pemikiran Islam, 20(1), 137-148. Retrieved from https://ejournal.metrouniv.ac.id/index.php/akademika/ article/view/439 [Indonesian] 